\section{REFERENCES}

Alexander, L., 2001: oral communication.

Difford, W., ed., 1965: Proceedings of the conference on the concept of a Sea-Grant University. Univ. of Rhode Island, 96pp.

Duce, R.A., 2001: GSO and John Knauss. Oceanography, this issue.

Farrington, J.W., 2001: Sverdrup, Johnson, and Fleming's The Oceans Revisited: What of the Future of Graduate Education in Ocean Sciences? Oceanography, this issue.

Inman, D., 2000: Reflections on oceanography at Scripps at the end of World War II, Oceanography. In: The
Making of a Science-People, Institutions and Discovery. Office of Naval Research, La Jolla, CA.

Knauss, J.A., 1990: The Stratton Commission-Its history and its legacy. Oceanography, 3(1), 53-55.

Lill, G., A. Maxwell and F. Jennings, 1959: The Next Ten Years in Oceanography. Office of Naval Research Technical Report.

Miloy, J., 1983: Creating the College of the Sea: the Origin of the Sea Grant Program. Texas A\&M University Sea Grant College Program, TAMU-SG-83-604, 64 pp.

Saalfeld, F., 2001, written communication.

Weisberg, R.H., 2001: An Observer's View of the Equatorial Ocean Currents. Oceanography, this issue.

\title{
The South Seas, the Indian Ocean, and the 1997-1998 El Niño: Influences of John Knauss
}

\begin{abstract}
1W hile walking back to my graduate student lodgings on a snowy winter day in Ithaca, New York, I learned from my roommate that his brother had a fellowship from Scripps to go to the South Seas for the summer. This sounded good to me, so I wrote and was accepted. When I arrived in La Jolla, I was told that I would work for a 35-year old graduate student, John Knauss, and instead of the South Seas, we would just be going south of San Diego. But it seemed like fun anyway, and I made the Dorado cruise aboard the R/V Horizon, a 150-foot seagoing tug.

Dorado had all the elements of an oceanographic venture: I was seasick and listened to the rumors that we would land in Manzanillo and could take the bus home (not true!); the seas were so high that all the fish in the aquarium died; and one night while we were sitting out on the fantail, I saw all the stars disappear on one side: it was a giant wave that had blocked them out. But we all survived, and the one picture that I truly remember is John sitting in the lab with a big globe planning his next expedition. This seemed irresistible: doing science and being an explorer.

I asked John how to became an oceanographer; he said finish your degree and write to me. By then, he had taken a new job as Dean of the Graduate School of Oceanography at the University of Rhode Island, and I became his first post-doc. We met in Singapore and spent six months working with Bruce Taft studying the currents in the equatorial Indian Ocean, as part of the International Indian Ocean Expedition. John's work with Bruce was important there because it showed how the equatorial undercurrent was stable in one direction, unstable in the other-an unexpected result, and one
\end{abstract}

that helped lay the groundwork for the theoretical understanding of the equatorial current system.

John and I overlapped again at Joint Oceanographic Institutions in Washington when I was President and he was a member of the Board of Governors. We talked frequently while he was my predecessor as Administrator of the National Oceanic and Atmospheric Administration (NOAA). One of the topics he focused on at NOAA was the development of an observation and modeling capability for El Niño under John, the TOGA TAO array was perfected and maintained, and he started the process for the joint university/government enterprise called the International Research Institute, now housed at Columbia University on the Lamont-Doherty Earth Observatory Campus in a new building.

By the time the largest El Niño of the century started in 1997, thanks to what John had supported, we were well prepared to monitor its evolution. Unlike the El Niño of 1982-1983, which was well underway before anyone was really aware, the 1997-1998 event was carefully tracked and continual forecasts of El Niño-related weather were provided globally.

I am grateful to Scripps and to John for starting me on my oceanographic career, and introducing me to so many people who have become lifelong friends. As with many famous oceanographers of the past, John's mentoring as well as his accomplishments have been an important part of the development of the field of oceanography.

D. James Baker Washington, DC USA 